\title{
LXXXII. On retaining water in rocks for summer use
}

\section{Mr. William Smith M.Y.P.S.}

To cite this article: Mr. William Smith M.Y.P.S. (1827) LXXXII. On retaining water in rocks for summer use, Philosophical Magazine Series 2, 1:6, 415-417, DOI: 10.1080/14786442708674354

To link to this article: http://dx.doi.org/10.1080/14786442708674354

$$
\text { 曲 Published online: } 10 \text { Jul } 2009 .
$$

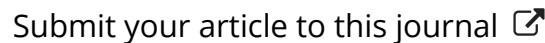

Џ Article views: 3

Q View related articles $₫$

4 Citing articles: 1 View citing articles 준 


\section{$\left[\begin{array}{ll}415 & 3\end{array}\right.$}

LXXXII. On retaining Water in Rocks for Stmmer Use. By Mr. William Smith, Engineer, M.Y.P.S. *

A $S$ practical applications of knowledge acquired from geology in relation to the comforts and conveniences of man in a most essential article of life, must be considered matter of importance, I hope to be excused for troubling the Society with a detailed account of what I may call a Geological Reservoir of water made in the hills near Scarborough in the dryest summer this country has experienced for sixty years.

We know from the annual variation of springs, that rocks hold a much greater quantity of water in winter than in summer; and we further know, that in wet seasons rocks hold periodically much more than their annual average quantity both in winter and summer: and hence the question as to the possibility of retaining water in rocks for summer use is decided by the annual and periodical operations of nature.

For the means of altering or improving some of these natural operations, so as to render the irregular supply of water which falls upon the earth more convenient to the general purposes of man, we must resort to geology; - to find what stratum is fitting for the object, and what site in the range thereof; what the rock lies upon; what stratum or diluvium covers it, and the dip, rises, and troughs or undulations in the strata.

I have for many years entertained notions of the practicability of making use of rocks as subterraneous reservoirs of water, in some cases extensive enough for the use of canals: and once, in a Report on Springs, suggested such a plan to one of our canal companies. But for the use of towns and dwelling-houses, many situations may be found where the joints of a rock are capacious enough for penning up winter water therein, for use in even the dryest summers; as many springs which then fail, produce a superabundant quantity in winter.

This was the state of the first springs anciently taken from adjacent hills to supply the town of Scarborough; which supply has been from time to time increased and improved at the expense of the Corporation. Within a few years new pipes have been laid at a great expense.

Still however, in the summer months, when there was much company in the place, water was deficient; and the commissioners for improving the town undertook to search for more water on the hill sides about a mile and half distant.

In the month of May last a small quantity was found to

* Read to the Yorkshire Philosophical Society, March 1827; and communicated by the Rev. W. V. Vernon, Pres. Y.P.S. 


\section{$416 \mathrm{Mr}$. Smith on retaining Water in Rocks for Summer Use.}

issue from a bore-hole made several years since for draining the land. On cutting an open channel up to this, the discharge increased and at the depth of nine or ten feet amounted to twenty-four hogsheads per hour. This encouraged them to proceed; and the channel under my direction was deepened four feet, when the discharge became for some time fifty or sixty hogsheads per hour.

Suspecting from an intermediate and subsequent diminution that we had drawn off a confined stock of water, and that the regular run of the spring at the end of a dry summer might not be found sufficient, I suggested the propriety of damming up the produce of this spring for summer use, as the previous supply was more than sufficient for the town in winter.

The circumstances were favourable for the purpose, as there was no other known issue of water from the rock in that hill, which is about a mile long, narrow on the top, and insulated in all the upper part of its stratification. The same rock is not opened or known any where else on these hill sides, but in a deep valley which separates the insular hill from the main and higher hill of Falsgrave Moor. In the upper end of that valley a spring was opened several years since in the same kind of rock, and was brought with a declivity of thirty or forty feet round the south end of the insulated hill, near to and high enough to run into the opening made to the new spring. This was sufficient to prove the general rise of the rock westerly in the base of the insular hill, and beneath an isthmus connected with the main ridge of Falsgrave Moor and Seamer Beacon. The rock in which the spring was found is a yellowish finegrained crumbly sandstone, in thick beds, with open irony joints, the same as in the cliff south of Scarborough Spa. From the quantity of carbonaceous matter in it, it is here called "s coly grit." This sandstone, with its overlying and alternating clays, is analogous in position to the clay and sand and sandstone between the cornbrash and great oolite rocks. At the depth of ten feet the rock was found covered with regular clay about four feet thick; on this a mark of coal, and a thin bed of hard stone full of imperfect vegetable impressions; and up to the surface a very tenacious slidden clay. The rock was found, by boring through it, to be ten feet thick, lying on clay. The channel excavated up to the spring about thirty or forty yards long, and fifteen feet deep, at the upper end was entirely in a very tenacious clay partly diluvial, with - a few rounded stones in it deeply covered by slidden clay. Within four feet of the edge of the rock lay gravel (deeply covered also with slidden clay), consisting of large and small boulders 
of whinstone, granite, mountain-limestone, \&c. which gravel, between the clay and the face of the rock tapered downward "to nothing" in the bottom of the excavation.

About two yards within the edge of the rock (which was nearly as upright as a wall) a basin six feet in diameter and four feet deep was excavated, to receive the water flowing from the joints of the rock. Cast-iron pipes branching from the main line of pipes were laid up to this basin, to receive the regular flow of the spring, which before the end of summer was reduced to less than six hogsheads per hour. The clay channel, in the bottom of which the pipes were laid, was refilled with clay and puddled, so that no water could pass from the rock but through the pipes. The end of the last pipe was closed, and a vertical aperture made for receiving the run of the spring. No further contrivance was required for stopping the water and damming it up in the rock, than an open vertical pipe ground to fit tight into the aperture in the horizontal pipe ; and this to the height of four feet was done by pieces of pipe, each a foot in length, tight-fitting one into another for the convenience of wholly or partially damming or drawing off the stored water as occasion might require; the water being allowed to run in at the top of the pipe.

Atter the rainy days in the beginning of November last, these short pieces of pipe were put in one after another, and found to dam up the water in the joints of the rock to the height of four feet, which from the quantity wasted last summer during the progress of the works, was calculated to contain 5000 hogsheads. The vertical pipe being since closed at top, (and lately also the main iron pipe, the whole of the water from those parts becomes forced into the cavities of the rock, and now stands 14 feet deep at the spring, or 10 feet higher than we calculated upon penning it; so that the subterraneous reservoir may contain 12,000 or 15,000 hogsheads of water. This will be ascertained in the summer as it is drawn down from time to time into the new arched reservoir in the town. This reservoir, formed of a brick cylinder 18 feet deep, sunk in the ground, and covered by a dome 40 feet span and 20 feet high, surrounded by a strong bank of earth, is calculated to contain 4000 hogsheads.

Scurborough, Feb. 5, 1827.

William Smith. 